\title{
Cardiac involvement in laminopathies - short invited review
}

\author{
Zajęcie serca w laminopatiach - praca poglądowa na zaproszenie Redakcji \\ GERARDO NIGRO'1, а, в, NICOLA CARBONI', в , MICHAL MARCHEL 3, в,

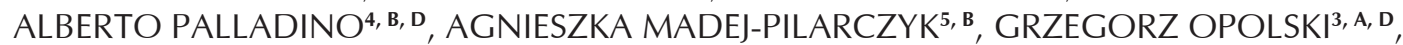 \\ IRENA HAUSMANOWA-PETRUSEWICZ ${ }^{5,}$, LUISA POLITANO ${ }^{6, \text { A, c-G }}$ \\ ${ }^{1}$ Department of Cardiorespiratory Sciences, Arrhythmologic Unit, Second University of Naples, Italy \\ ${ }^{2}$ Neurology Division, San Francesco Hospital, Nuoro, Italy \\ ${ }^{3}$ Department of Cardiology, Medical University of Warsaw, Poland \\ ${ }^{4}$ Cardiomyology and Medical Genetics, Second University of Naples, Italy \\ ${ }^{5}$ Neuromuscular Unit, Mossakowski Medical Research Centre, Polish Academy of Science, Warsaw, Poland \\ ${ }^{6}$ Cardiomiology and Medical Genetics, Department of Experimental Medicine, Second University of Naples, \\ Italy
}

A - Study Design, B - Data Collection, C - Statistical Analysis, D - Data Interpretation, E - Manuscript Preparation, $\mathbf{F}$ - Literature Search, $\mathbf{G}$ - Funds Collection

Summary Mutations in lamins, which are ubiquitous nuclear intermediate filaments, lead to a variety of disorders, described as laminopathies or nuclear envelopathies, that include both X-linked and autosomal dominant forms of Emery-Dreifuss muscular dystrophy (EDMD), dilated cardiomyopathy with conduction system defects (DCM-CD), limb girdle muscular dystrophy 1B (LGMD1B) with atrioventricular conduction disturbances, Dunnigan-type familial partial lipodystrophy (FPLD), mandibuloacral dysplasia (MAD), and autosomal recessive forms of axonal Charcot-Marie-Tooth (ARCMT2, CMT2B) and progeria syndromes. Cardiac involvement in laminopathies can be isolated or more frequently associated with muscle involvement. The vast majority of patients develop dysrhythmias after the age of 30 years, and many undergo pace maker (P.M.) or cardioverter defibrillator implantation; heart failure is relatively frequent after the age of 50 but it occurs less commonly than dysrhythmias. Both tachy-arrhythmias and brady-arrhythmias may occur also in LMNA mutated patients presenting a congenital or early onset of the disease. Sudden cardiac death (SCD) is the modality of exitus most frequently observed even in implanted patients, indicating that subjects carrying LMNA gene mutations are at high risk of sudden death and that P.M. implantation is unable to protect them against this dramatic event. The identification of parameters able to stratify the patients at risk is of considerable utility in clinical practice.

Key words: laminopathies, cardiolaminopathies, LMNA mutations.

Streszczenie Mutacje lamin, które są powszechne występującymi filamentami pośrednimi, prowadzą do różnych zaburzeń, zwanych laminopatiami lub zaburzeniami błony jądrowej, do których należy zarówno związana z chromosomem X, jak i autosomalna dominująca postać dystrofii mięśniowej Emery'ego-Dreifussa (EDMD), kardiomiopatia rozstrzeniowa z wadą układu przewodzącego (DCM-CD), obręczowo-kończynowa dystrofia typu 1B (LGMD1B) z zaburzeniami przewodzenia przedsionkowo-komorowego, rodzinna częściowa lipodystrofia typu Dunnigana (FPLD), dysplazja żuchwowo-obojczykowa (MAD) i autosomalna recesywna postać choroby Charcota-Mariego-Tootha (ARCMT2, CMT2B) oraz zespół progerii. Zajęcie serca w laminopatii może być izolowane lub częściej związane z włączeniem mięśni. U zdecydowanej większości pacjentów występuje arytmia po ukończeniu 30 lat, a wielu przechodzi wszczepienie rozrusznika serca (PM) lub kardiowertera-defibrylatora; niewydolność serca występuje stosunkowo często po 50. roku życia, ale występuje rzadziej niż arytmie. Tachycardia i bradykardia mogą występować także u pacjentów z mutacjami LMNA mających wrodzoną lub wczesną postać choroby. Nagła śmierć sercowa (SCD) jest rodzajem zgonu najczęściej obserwowanym nawet u pacjentów po zabiegu wszczepienia, co wskazuje na to, że osoby z mutacją genu LMNA są narażeni na wysokie ryzyko nagłego zgonu i że wszczepienie rozrusznika serca nie jest w stanie ich uchronić przed tym dramatycznym wydarzeniem. Identyfikacja parametrów pozwalających na podział pacjentów na grupy ryzyka ma istotne znaczenie w praktyce klinicznej.

Słowa kluczowe: laminopatia, kardiolaminopatie, mutacje LMNA.

Fam Med Prim Care Rev 2015; 17(4): 327-329

Lamins are ubiquitous nuclear intermediate filament proteins that form a scaffold, termed nuclear lamina, at the nuclear periphery. A small fraction of lamins also localize throughout the nucleoplasm. Lamins, binding to a growing number of nuclear protein complexes, provide nuclear stability, help connect the nucleus to the cytoskeleton, and contribute to modulate chromatin organization, gene regulation, genome stability, and cellular differentiation [1].
Considerable interest has been focused on the nuclear envelope (NE) in the last 15 years following the realization that several human diseases link to defects in genes encoding NE specific proteins, most notably A-type lamins and emerin.

Mutations in lamin $\mathrm{A} / \mathrm{C}$ lead to a variety of disorders, described as laminopathies or nuclear envelopathies, that affect striated muscle, heart, nerves, adipose tissue, bone or cause premature ageing. 
They include both X-linked [2] and autosomal dominant forms [3] of Emery-Dreifuss muscular dystrophy (EDMD), dilated cardiomyopathy with conduction system defects (DCM-CD), limb girdle muscular dystrophy 1B (LGMD1B) with atrioventricular conduction disturbances [4], Dunnigan-type familial partial lipodystrophy (FPLD), mandibuloacral dysplasia (MAD) and autosomal recessive forms of axonal Charcot-Marie-Tooth (ARCMT2, CMT2B) [5]

Recent findings suggest that lamin mutations can decrease nuclear stability, increase nuclear fragility, and disturb mechano-transduction signaling, possibly explaining the specific defects in many laminopathies $[6,7]$.

Both LMNA-related myopathies (LM) and cardiomyopathies (cardiolaminopathies, CLM) have been described. LM represent the more consistent subgroup of diseases due to mutations in LMNA gene, with three main different phenotypes based on the distribution of muscle weakness or age at onset: LGMD1B, EDMD2, and a form of congenital muscular dystrophy (MDCL). However all may be associated with the same mutation and present in the same family [8-11]; in addition, considerable clinical overlap exists among these three entities suggesting they should be considered as a continuum clinical spectrum. Indeed, heart is involved in all three entities, with similar features [11] and interestingly, heart presentation may precede onset of muscle weakness. Creatine kinase is usually normal or mildly elevated.

In CLM the first signs of cardiac disease proved to be often silent; ECG findings consist in cardiac rate and rhythm abnormalities, followed by sinus node alterations or progressive atrio-ventricular blocks. A number of subjects develop atrial fibrillation or flutter evolving in dilated cardiomyopathy whose severity ranges from mild to moderate to severe, leading to heart failure requiring in some cases heart transplantation [12].

Mutations in LMNA A/C gene have been found in $6 \%$ of all forms of dilated cardiomyopathy and in up to $33 \%$ of those with conduction system disturbances.

Vytopil et al. [13] studied the frequency of LMNA mutations associated to different cardiac and skeletal muscle phenotypes in 166 patients subdivided into four groups: Emery-Dreifuss muscular dystrophy (EDMD), isolated heart disease, isolated muscular dystrophy, and idiopathic hyperCKemia. They showed that the presence of heart involvement and age of onset are distinguishing features separating patients with EDMD and LMNA mutation from those LMNA/ /STA negative, while distribution of myopathy is not a reliable diagnostic criterion.

Furthermore an evident intra- and inter-familial variability has been observed, with cases showing a rapid and negative prognosis caused by sudden cardiac death or quick deterioration of cardiac status, and familial cases with milder disease course characterized by low prevalence of atrial fibrillation and dilated cardiomyopathy and no evidence of sudden death [12].

Cardiac involvement does not significantly differ in patients with neuromuscular phenotype from those with selective cardiac disease [12]. It usually manifests first with low $\mathrm{P}$ wave and prolonged PR interval, narrow QRS complexes at the ECG. The vast majority of patients may develop dys- rhythmias after the age of 30 years, and many undergo pace maker (PM) implantation; heart failure is relatively frequent after the age of 50 and occurs less commonly than dysrhythmias [14-16]. To be noted that atrial fibrillation and A-V blocks can be present also in laminopathies with congenital or early onset [10].

Interestingly, sudden cardiac death (SCD) was the modality of exitus most frequently observed even in implanted subjects, indicating that they are at high risk of sudden death and that PM is unable to protect them against this dramatic event [12]. SCD is attributed to the development of lifethreatening arrhythmias that may occur in the presence of normal left ventricular systolic function.

Not invasive parameters able to stratify the patients at risk to present SCD could be of considerable utility in clinical practice. Among them, P-wave dispersion, an independent risk factor for the development of atrial fibrillation, has recently been reported to be significantly increased in subjects carrying LMNA gene mutations, despite a preserved systolic and diastolic cardiac function [17]. Russo et al. studied QTc dispersion (QTC-D) and JTc dispersion (JTc-D), because heterogeneity of ventricular repolarisation, stated by these electrocardiographic parameters, is considered to provide an electrophysiological substrate for malignant arrhythmias and sudden death [18]. They observed that, compared to the healthy controls, LMNA mutated patients present increased values of QTC-D and JTc-D [18].

The few studies performed on a limited number of patients showed that the factors associated with an unfavorable prognosis are ejection fraction $<45 \%$, non-sustained ventricular tachycardia, male gender and any form of atrioventricular block.

In a retrospective longitudinal study on a large number of families whose index case was affected from cardiolaminopathy, a high rate of major cardiac events was reported, including malignant ventricular arrhythmias and heart failure, usually occurring in patients already affected by dilated cardiomyopathy [19]. However, from a phenotypical point of view, myocardial involvement in laminopathies is indistinguishable from other forms of idiopathic dilated cardiomyopathy. Given the lack of evidence, indications for an implantable cardioverter-defibrillator for primary prevention in this context are the same as conventional indications for other forms of idiopathic dilated cardiomyopathy [21].

In clinical practice, a story of competitive sport and the presence of a non-missense LMNA gene mutation are considered as predicting factors of sudden cardiac death. In general, malignant ventricular arrhythmias tend to occur in subjects carrying at least two of the following variables: mutations other than missense on LMNA gene, ejection fraction $<45 \%$ at first clinical evaluation, male sex and nonsustained ventricular tachycardia [20]. These findings help understanding the natural course of cardiolaminopathies and provide the clinicians with important suggestions on how to prevent sudden cardiac death [22].

\section{Acknowledgements}

The support of Telethon UILDM (Grants GUP 11001C and GUP $11002 \mathrm{~L}$ to LP) is greatly acknowledged. We also thank patients and families for their collaboration and constant support.

Source of funding: This work was funded by Telethon UILDM (Grants GUP 11001C and GUP 11002L to LP).

Conflict of interest: The authors declare no conflict of interests.

\section{References}

1. Wehnert MS, Bonne G. The nuclear muscular dystrophies. Semin Pediatr Neurol 2002; 9: 100-107.

2. Emery AE, Dreifuss FE. Unusual type of benign x-linked muscular dystrophy. J Neurol Neurosurg Psychiatry 1966; 29(4): 338-342.

3. Bonne G, Di Barletta MR, Varnous S, et al. Mutations in the gene encoding lamin A/C cause autosomal dominant Emery-Dreifuss muscular dystrophy. Nat Genet 1999; 21(3): 285-288. 
4. Muchir A, Bonne G, van der Kooi AJ, et al. Identification of mutations in the gene encoding lamins A/C in autosomal dominant limb girdle muscular dystrophy with atrioventricular conduction disturbances (LGMD1B). Hum Mol Genet 2000; 9(9): $1453-1459$.

5. Lattanzi G, Benedetti S, Bertini E, et al. Laminopathies: many diseases, one gene. Report of the first Italian Meeting Course on Laminopathies. Acta Myol 2011; 30(2): 138-143.

6. Davidson PM, Lammerding J. Broken nuclei-lamins, nuclear mechanics, and disease. Trends Cell Biol 2014; 24: $247-256$.

7. Benedetti S, Bernasconi P, Bertini E, et al. The empowerment of translational research: lessons from laminopathies. Orphanet J Rare Dis 2012; 7: 37.

8. Politano L, Carboni N, Madej-Pilarczyk A, et al. Advances in basic and clinical research in laminopathies. Acta Myol 2013; 32(1): 18-22. Review.

9. Mercuri E, Poppe M, Quinlivan R, et al. Extreme variability of phenotype in patients with an identical missense mutation in the lamin A/C gene: from congenital onset with severe phenotype to milder classic Emery-Dreifuss variant. Arch Neurol 2004; 61: 690-694.

10. Quijano-Roy S, Mbieleu B, Bönnemann CG, et al. De novo LMNA mutations cause a new form of congenital muscular dystrophy. Ann Neurol 2008; 64: 177-186.

11. Maggi L, D'Amico A, Pini A, et al. LMNA-associated myopathies: the Italian experience in a large cohort of patients. Neurology 2014; 83: 1634-1644.

12. Fatkin D, MacRae C, Sasaki T, et al. Missense mutations in the rod domain of the lamin A/C gene as causes of dilated cardiomyopathy and conduction-system disease. N Engl J Med 1999; 341: 1715-1724.

13. Vytopil M, Benedetti S, Ricci E, et al. Mutation analysis of the lamin A/C gene (LMNA) among patients with different cardiomuscular phenotypes. J Med Genet 2003; 40: e132.

14. van Berlo JH, de Voogt WG, van der Kooi AJ, et al. Meta-analysis of clinical characteristics of 299 carriers of LMNA gene mutations: do lamin A/C mutations portend a high risk of sudden death? J Mol Med (Berl) 2005; 83: 79-83.

15. Boriani G, Gallina M, Merlini L, et al. Clinical relevance of atrial fibrillation/flutter, stroke, pacemaker implant, and heart failure in Emery-Dreifuss muscular dystrophy: a long-term longitudinal study. Stroke 2003; 34: 901-908.

16. Bécane HM, Bonne G, Varnous S, et al. High incidence of sudden death with conduction system and myocardial disease due to lamins A and C gene mutation. Pacing Clin Electrophysiol 2000; 23(11 Pt. 1): 1661-1666.

17. Nigro G, Russo V, Rago A, et al. Regional and transmural dispersion of repolarisation in patients with Emery-Dreifuss muscular dystrophy. Kardiol Pol 2012; 70: 1154-1159.

18. Russo V, Rago A, Politano L, et al. Increased dispersion of ventricular repolarization in Emery Dreifuss muscular dystrophy patients. Med Sci Monit 2012; 18: CR643-CR647.

19. Pasotti M, Klersy C, Pilotto A, et al. Long-term outcome and risk stratification in dilated cardiolaminopathies. J Am Coll Cardiol 2008; 52: 1250-1260.

20. van Rijsingen IA, Nannenberg EA, Arbustini E, et al. Gender-specific differences in major cardiac events and mortality in lamin A/C mutation carriers. Eur J Heart Fail 2013; 15: 376-384.

21. Cabanelas N, Martins VP. Laminopathies: a Pandora's box of heart failure, bradyarrhythmias and sudden death. Rev Port Cardiol 2015 Feb; 34(2): 139.e1-5. doi: 10.1016/j.repc.2014.08.007. Epub 2015 Feb 3.

22. Menezes MP, Waddell LB, Evesson FJ, et al. Importance and challenge of making an early diagnosis in LMNA-related muscular dystrophy. Neurology 2012; 78: 1258-1263.

Address for correspondence:

Prof. Luisa Politano

Cardiomiologia e Genetica Medica

Dipartimento di Medicina Sperimentale

Seconda Università di Napoli

I Policlinico - Piazza Miraglia

80138 Napoli

Italy

Tel.: 390815665300

E-mail: luisa.politano@unina2.it

Received: 28.10.2015

Revised: 29.10.2015

Accepted: 29.10.2015 